\title{
FINANCING THE WELFARE STATE AND THE POLITICS OF TAXATION.
}

\author{
Nathalie Morel and Joakim Palme
}

CHAPTER 38 in Greve, B. (ed.) (2012). The Routledge Handbook of the Welfare State, Routledge, pp. 400-409.

In an era of 'permanent austerity' (Pierson, 2001) and financial crisis, the issue of financing welfare state provisions is topical. Moreover, the future of welfare state funding in countries with ageing populations is no doubt raising increasing interest in scholarly as well as policy circles. Yet the financing side of welfare provision has traditionally been given little attention and remains somewhat of a black box of the welfare state. The fact that some of the financing mechanisms have remained 'hidden' has added to the confusion about existing policy alternatives.

In developed countries, the demands on welfare state financing have been driven by the fact that, on average, gross public social expenditure across OECD countries has increased from $7 \%$ in 1960 to $19 \%$ in 2007 (SOCX, 2011). In the EU, this figure reaches as much as $26 \%$ of GDP (Eurostat, 2011). As such, the financing of social policy is a highly salient economic and political issue, marked by continued conflicts regarding to what extent and in what ways social policies should be financed and how the cost should be distributed. The financing and institutional mechanisms that have been put in place for the extraction of resources and their redistribution thus provide a direct insight into the different kinds of social contracts that underpin each and every welfare state, reflecting different conceptions of solidarity and different redistributive ambitions (Sjöberg, 2000).

The different financing mechanisms that support social protection systems not only have an impact on the redistributive outcomes of social policy, but also on the political legitimacy of social systems and social benefits and therefore on the willingness to pay, as well as an impact on the economy, not least in the way it affects the cost of labour but also, potentially, economic growth and competitiveness. The question of the economic impact and financial sustainability of the different modes of financing social policy has increasingly come to the fore since the 1980s, and even more so now in a context of increased economic globalisation and of financial crisis. Despite the crucial economic, political and social issues that are 
involved, the sociological and political scholarship on the financing of the welfare state remains surprisingly underdeveloped, even if there now seems to be a renewed interest in the field of fiscal sociology, including in relation to the welfare state (cf. Howard, 1997; Swank and Steinmo, 2002; Campbell, 2009; Manow, 2010; Béland, 2011).

In this chapter we start by discussing the main determinants of the financing needs of welfare systems. We then turn to the different sources of revenue and patterns of welfare state funding in the advanced industrial nations. This is not to deny the importance of funding social protection systems in development contexts but rather reflects the fact that most research has been focused on the rich part of the world and the emerging development-oriented research has given a lot of attention to the experience of industrialized nations (cf. Hujo and McClanahan, 2009; Barrientos, 2008). The third section analyses the politics of taxation and financing trends in the mature welfare states. In particular, we address the impact of the different financing techniques on employment and economic growth and on the political legitimacy and reform possibilities of the different social protection systems. The fourth section addresses the issue of the redistributive impact of the different financing techniques and underlines the importance of analysing the dynamics between how the financial resources are raised and spent. Finally, the chapter discusses the current and future challenges to welfare state financing in the face of increased globalisation and ageing populations. In the conclusion, we summarize the key lessons to be learnt from the analysis of welfare state financing.

\section{The cost of the welfare state: determinants of social expenditure.}

The current demands on funding for modern welfare states are the outcome of a century long development, where various social policy programmes have emerged, expanded and matured. This expansion can be related to two different types of factors: the extension of social rights, on the one hand, and the growth of needy populations, on the other (Kangas and Palme, 2007). The entitlement structure to social benefits, that is to say the social citizenship rights codified in national laws or collective agreements, determines the number of beneficiaries (by setting the eligibility criteria, for instance by specifying the age at which people can retire) as well as the level of benefits and thus impacts on the cost of a given programme. The demographic context has an impact on the social protection system's dependency ratio, that is to say on the number of beneficiaries in the system compared to the number of people 
financing the transfers. But demographics only explain a portion of the financing needs and financing possibilities of a given welfare state. How many people receive benefits and how many people there are to finance these benefits depends on economic factors such as employment levels. The number of unemployed people affects both the financing needs for unemployment insurance schemes and social assistance and the earning and taxing capacity of the country.

The demands on the financing systems are, to varying degrees, possible to influence by reforming the entitlement structure, for example by raising the legal retirement age, by reducing the level of benefits or lengthening the contribution period necessary to become entitled to a given benefit (such as unemployment benefits for instance). But there are also other ways in which governance could modify the dependency ratio and the fiscal sustainability of the welfare state. Increasing the tax base by boosting employment levels, raising taxes and/or social contributions to finance social expenditures, but also increasing family benefits to affect the birth rate and thus improve the demographic old-age dependency ratio in the long run, are other ways that can modify the financing needs and capacity of a given welfare system.

\section{Sources of revenue and modes of financing.}

As Richard Titmuss had pointed out more than a half century ago, social welfare, understood as the formal publicly financed and provided social programs, only constitutes one part of the welfare state. Occupational welfare (that is work-related benefits that are distributed by companies to their employees) and fiscal welfare constitute other important sources of welfare provision. This chapter is however focused on the analysis of the statutory social protection schemes, i.e. 'social welfare', while the growing importance of 'occupational' and 'fiscal welfare' is dealt with in another chapter of this volume.

Social protection systems rely on different sources of income, of which taxes (in the form of a share of general revenues or taxes earmarked for social protection purposes) and social contributions (paid by employers and/or employees) form the main part. Other sources of revenues such as returns on funding exist but ordinarily play only a marginal role. 
The source of financing is usually related to the characteristics of the benefits (Cichon et al., 2004:232). Universal benefits are normally funded from general tax revenues but they can be funded from mandatory contributions, possibly including contributions from the unemployed and non-workers. Means-tested social assistance benefits are typically funded from general tax revenues because the low-income recipients of these benefits might not qualify on the basis of accumulated contributions. Social insurance systems are usually financed through contributions from employers (payroll taxes) and workers/insured persons, sometimes complemented by government contributions. Here it is important to note that while the formal share of state funding is mostly low, large deficits in insurance programs are typically covered by general revenue funding (Sjöberg, 2000). Finally, provident funds and individual account defined contribution plans are financed by workers' contributions withheld from wages, often without a corresponding contribution from employers.

Social protection systems and individual social protection schemes are generally categorized according to whether they are predominantly tax financed or contribution financed, but most systems actually combine different types of revenues. Nonetheless, core differences between welfare regimes reflect the diversity of tax instruments used to fund the different types of welfare states.

The patterns of welfare state funding in Europe and the other advanced industrial nations have to be seen in the light of the different social policy models that have emerged over the past century. The Bismarckian countries of Continental Europe follow the insurance principle, with social contributions as the main source of funding (over $65 \%$ of social protection receipts, the main part being paid by employers) and a historically small role for taxation. Taxation has however been of increasing importance in this model in more recent years (Manow, 2010). While the Beveridge system initially placed a strong emphasis on contributions as a mode of financing, the importance of general taxation has increased in Beveridgean countries, to about $50 \%$ of social protection receipts in the UK. In the Nordic countries, social protection systems were predominantly tax funded but the post-war expansion was made possible by increased employer contributions. Yet general government revenue still accounts for over $60 \%$ of social protection receipts in Denmark and Norway. Social contributions paid by employees, while still comparatively low, have been on the rise in recent years in the Nordic countries, notably in Finland and Sweden. 
Thus, while there are still clear differences in the funding structure of different welfare states, these differences have gradually become less pronounced, not least amongst the European countries. There are still significant cross-national differences in levels and patterns of public social spending and taxation, however. For instance, public spending and taxation levels are comparatively low in the English-speaking countries, and much higher in the Nordic welfare states (Obinger and Wagschal, 2010).

Looking at public spending levels and types and levels of taxation does not, however, give a full picture of welfare provision in the different welfare states. Indeed, fiscal welfare, in the form of tax expenditures (i.e. tax exemptions, deductions, allowances or credits to targeted groups or specific activities) constitutes a sometimes important element of welfare provision, not least in the English-speaking countries where public social protection expenditure is relatively low (Adema and Ladaique, 2009). Because tax expenditures, which can serve to subsidize different private schemes such as health or pension insurance as well as family policy (such as the Child Tax Credit in the US and the UK, or the tax splitting system in France or Germany to support families with children), do not involve monetary transfers, they do not appear in traditional social protection accounting systems, but they do represent income forgone by the government and should in fact be counted as part of overall public social protection expenditure. As Howard (1997) has shown for the US, tax expenditures represent important sums of government revenue foregone and very much constitute some sort of "hidden welfare state" (see also Hacker, 2002 and the chapter by Sinfield in this volume). In recent years, fiscal welfare measures have been on the increase in all welfare states (De Deken, 2009), which constitutes another element of convergence in the financing techniques used across welfare regimes. This is particularly the case in the field of pensions. But other measures such as tax deductions for childcare and for household services have been introduced, both in Continental European countries as well as in the Nordic countries.

\section{The politics of taxation and financing trends in the mature welfare states.}

The reforms and progressive convergence in the financing techniques used can be understood in light of the relative strengths and weaknesses of the different modes of financing as well as of the changed demographic and economic contexts which all welfare states are facing. However, the importance of politics should not be underestimated either with regard to maintaining the existing order or for changing it. 
In the case of tax-financed systems, the main issue has to do with the increasing fiscal and budgetary constraints that have been placed on governments (linked to increased unemployment and ageing, along with economic globalisation and tax competition), making social policy expenditure a more salient issue, and one on which there is pressure to cut back. In times of budgetary constraints, resource allocation between social policy and other fields of expenditure (such as defence or education for instance) becomes a more contested process, making benefit levels more subject to annual budget decisions and thus less stable than in contribution-based systems. The growing political resistance to tax increases in all countries puts a further strain on funding possibilities. On the plus side, general revenue financing provides greater flexibility and overall government control over public sector financing, giving governments greater leeway in defining spending priorities.

Contribution-financed systems or schemes, which are funded and most-often administered by bipartite or tripartite governing bodies independently of the government budget, have historically tended to be more generous and less susceptible to retrenchment than tax-funded schemes since contributions are earmarked for specific benefits and thus do not depend on overall government budget decisions. As such, there is evidence of greater willingness to contribute wherever there is earmarking and the use of funds is known, and the political legitimacy of contribution-financed systems thus tends to be high, especially if benefits are attractive and income-related (Manow, 2010). Indeed, contributors feel they have a stake in the system and that the money they pay in will come back to them in the form of a 'deferred wage' and an earned social right.

Contribution-financed schemes are for the most part based on a Pay-as-you-go (PAYG) system, which means that the benefits paid out (for pensions, sickness, unemployment, and maternity leave) are paid directly from current workers' contributions. The financial sustainability of such systems, at least in the case of defined-benefit schemes, thus very much depends on the dependency ratio between the number of people receiving benefits and the number of people paying in contributions. In this context, it has been suggested that funded pension systems could be a solution. But this is only partly true: the effect of the changing age structure will be the same in funded- and PAYG-systems, unless pension funds are invested internationally - which involves other kinds of risks. In the case of short-term benefits (sickness, unemployment, maternity) contributions can be adjusted relatively quickly to 
changing economic and demographic realities, but pensions require much more long-term planning (Cichon et al., 2004). In Europe, where defined benefit contribution-financed pension schemes largely predominate, population ageing, combined to a shrinking workforce due to rising unemployment, along with a strategy of labour-shedding in the Continental welfare states in the 1980s and 1990s (Esping-Andersen, 1996), have put considerable strain on contribution-based PAYG schemes, especially in the field of pensions which suffer huge deficits and which therefore have been the site of (often very contested) reform attempts. The picture is slightly different where tax-financed schemes play a lager role, e.g. in the UK, Ireland, Denmark and the Netherlands. The introduction of defined contribution systems in Sweden and Italy should be seen in a context of strong political ambitions to control expenditure developments.

Budget deficits are also found in the field of contribution-financed healthcare systems where financers and providers of care are separate, and where there is thus little control over the demands placed on healthcare providers. In tax-financed healthcare systems, on the other hand, the state is often also the provider of care and can exercise more control over spending (Palier, 2004).

Yet the problem that has appeared in contribution-financed systems that has perhaps become of most concern has to do with the way social contributions, and especially employers' contributions, affect the cost of labour thus making firms potentially less competitive in the global economy and reducing the demand for labour in countries where employers' contributions are high. As different scholars have argued, high fixed labour costs have constituted an obstacle to private job growth, and especially so for low-skilled jobs and in the low-productivity service sector, more so than in countries relying predominantly on income taxation (Scharpf, 2000; Kemmerling, 2002; Manow, 2010). High social contributions may also provide incentives for informal sector activity rather than formal employment for both employers and workers. This negative impact on labour demand and supply may exacerbate the deteriorating dependency ratio between the number of people paying in and the number of people receiving benefits of contribution-financed welfare systems.

This issue was exacerbated in the 1980s and 1990s when raising social contributions was perceived as the most politically viable solution. Indeed, as Manow (2010) has argued, governments essentially could respond in three ways to the fiscal stress caused by diminished 
growth combined with increased welfare spending demands: they could cut costs, run a higher debt, or increase revenue. According to Manow, these basic strategies were associated with varying political costs depending on how the welfare state is financed in a given country and depending on how easy it was to run a higher public debt. Increasing social contributions proved politically less problematic, not least as such measures are less visible. Manow gives several reasons for this. One is that while most tax increases have to be legislated, social insurance contributions often rise automatically whenever revenue falls short of expenses. Moreover, such automatic increases can be attributed to secular trends like demographic aging or costly medical progress, which dilutes direct political responsibility for increases. Another reason is that earmarked social insurance contributions are not formally part of the government's budget but go into the fiscally independent and more autonomous budgets of the social insurance schemes. Thus, if the government budget is not directly affected, the government has no or little political interest in preventing contribution hikes. In other words, a government's political capacity to cut costs as well its political interest to do so are generally much less developed in contribution-financed welfare states.

This explains that there was a general trend towards increasing the role of social contributions in continental European welfare states, and also why tax-financed welfare states started to introduce social contributions that did not weigh directly on the state's budget.

However, such an increase in social contributions in the continental welfare states also exacerbated the problem of high non-wage labour costs and hampered job growth, thus contributing to high and persistent unemployment. By the mid-1990s, this detrimental impact on employment and growth was widely recognized and became one of the main reasons for attempting to reform and restructure the way these welfare systems are funded. Various measures have since then been taken to reduce non-wage labour costs, especially by relieving employers from paying social insurance contributions for certain groups of workers such as the low-skilled, low-paid workers, but also for young people to help them access the labour market, as well as for the disabled or the long-term unemployed. Social contribution exemptions have also been introduced in specific sectors, especially the service sector (eg. for home care and household services) in order to encourage the creation of jobs in this sector, but also to provide incentives for such jobs to operate within the formal economy rather than on the black market (Morel, 2007). The long-term risk of giving rebates to low paid jobs is that old and inefficient structures are cemented (Palme et al, 2009). 
Another issue that has appeared in relation to contribution-based systems is that given the deteriorating economic environment and employment conditions, more and more people do not qualify for social insurance benefits due to a lack of sufficient and continuous attachment to the labour market. In the 1990s, the increasing cost of non-contributory social assistance benefits paid out to the long-term unemployed, along with other flat rate social minima such as those for the elderly or the disabled, became an increasing problem for contributionfinanced welfare systems as governments were tempted to pass off these costs to the social insurance funds. There was an increasing feeling amongst the social partners that these costs should not be paid out of social contribution funds but rather out of tax-financed social solidarity (Palier, 2010).

This growing discontent of the social partners combined to the above-mentioned dominant interpretation at that time of the negative impact of high payroll taxes on job growth have led governments to seek to expand the range of funding sources, especially through general revenue taxes and/or earmarked taxes. These new sources of funding are used to finance specific benefits and / or to improve the financial equilibrium of different schemes. There has been a substantial increase in the use of earmarked taxes (these represented $2.17 \%$ of GDP in 2008 for the EU15 against only $0.55 \%$ in $1997-$ Eurostat, 2011) as these present the double advantage of enjoying the same kind of political legitimacy as social contributions while introducing more equity in social protection systems by broadening the tax base instead of having the funding rest on the working population alone.

\section{Redistributive impact of the different financing techniques}

Other trends that span all welfare regimes include a shifting of costs to the private sector and to individuals. We can thus observe a general increase in the use of user fees in the areas of service provision such as childcare, elderly-care, and health care. Another important method, as previously discussed, has been the increasing use of fiscal measures to encourage the development of voluntary and mandated private insurance schemes in areas such as healthcare, sickness benefits and old-age provision (De Deken, 2009).

While it is fairly clear that this latter trend towards shifting the costs to the private sector affects the redistributive profile of welfare systems negatively due to the fact that tax 
expenditures benefit the wealthier segments of the population in a way that has been shown to be highly regressive (cf. Howard, 1997), and while this is likely to hold true also in the case of increasing user-fees, it is more difficult to assess the redistributive impact of the other trends.

The move towards more tax funding in continental Europe could improve the redistributive profile of these welfare states by taxing all forms of income, including capital income. Taxes also tend to be more progressive than social contributions. Indeed, social contributions are often regressive because they do not have a basic tax allowance, which reduces the relative tax burden on low-income earners, but do have ceilings on contributions, which reduce the relative tax burden on high-income earners. They are also levied from a much smaller proportion of the population than taxes. Consumption taxes have a more ambivalent impact. On the one hand, these are hard to avoid even for the owners of highly mobile assets. But on the other, if applied at a uniform rate, their distributive impact tends to be regressive since poor people have to spend a larger share of their income. Split tax rates (one for luxury goods and one for basic needs) have a less negative impact.

The past decades have seen a trend towards less progressive tax scales, which could suggest that the income tax systems have become less redistributive. However, this may not necessarily hold true. Firstly, the flattening of the tax rates has been accompanied by a broadening of tax bases. Secondly, the redistributive effect is also affected by the level and structure of social expenditure, which implies that any serious analysis of the redistributive effects of the welfare state has to analyse the combined effects of revenues and expenditures (Korpi and Palme, 1998). It is furthermore important to underline that social insurance systems tend to be redistributive because the risk of getting sick or unemployed falls unevenly on the shoulders of low-income people. This effect tends to be much stronger than some of the "imperfections" on the contribution side.

\section{Current and future challenges}

New challenges have called into question present financing arrangements and raise questions regarding the future financial sustainability of welfare states. Economic globalisation is imposing constraints on national tax policies and can lead to tax competition and a race to the bottom, while increased migration sets pressure on welfare states to harmonise welfare 
policies and their financing. High unemployment in many European countries has further reduced the possibility to raise revenue. In addition, many countries will have to deal with the consequences of the financial crisis (see chapter by Farnsworth and Irving in this volume).

The future of the welfare state is likely to hinge on the ability for nation states to levy taxes and social security contributions on their populations. Yet, also the economically most advanced nations are experiencing shrinking workforce, eroded tax bases, population ageing and increased demands on social services from increasing parts of the populations. Faced with these new challenges, some countries have reduced budgetary deficits by not only modifying the structure of the financing of their social protection systems, but also by transferring some of the costs to the private sector, with important economic, social and political implications. Not only are such tax expenditures regressive in terms of distributional outcomes, they also deprive the state of the resources to make the necessary investments in the current and future workforce and tax base of the nation.

Economic globalisation and the resulting tax competition appear to have conditioned the role of political parties and other domestic factors (Ganghof, 2008). Hence, not only have the corporate tax rates converged, the relative strength of political parties appears to have had no effect on the changes, although this does not hold true for all forms of taxation. The EUcontext adds some issues with regard to welfare state funding and this despite the fact that both the taxation system and the welfare state by and large are outside EU competencies. One important exception is the protection of migrant workers. Given the differences with regard to financial structures this introduces certain tensions when migrants move between different kinds of systems, or, in the case of cross-boarder work, work and live in different systems/countries. The growing importance of the European Court of Justice also opens up for an increased significance of the EU-context, for example when it comes to the health-care systems and the rights of EU-citizens to get publicly funded care provided in another EU Member State than that he or she resides in.

\section{Conclusion}

The future funding of the welfare state is about increased demands under obvious constraints, and hence about increasing the tax base and about policy reform and innovation. The alternative is a future with more modest entitlements. As such, the transformation of the fiscal structure is part and parcel of welfare state transformation and restructuring. 
The European populations have a lot to gain in terms of securing the future tax bases by pursuing social investment policies that broaden the tax base, improve the skills of the population and improve the gender balance in paid work (Morel, Palier and Palme, 2012). Combating unemployment, and especially long-term unemployment, is crucial both for increasing the tax base and securing receipts, and for diminishing expenditure, while augmenting the skills of the population is likely to reduce the risk of unemployment and to increase the quality of jobs and wages, and thus of revenues. Finally, the presently low female labour force participation rates in many countries represent something of a reserve army of potential taxpayers.

There also appears to be room for innovation with respect to financing mechanisms. An example is the French CSG (General Social Contribution) introduced in 1991 and levied on all forms of income, including capital and property income, which suggests that, even in an era of supposedly "permanent" austerity, the state can find new ways to actually expand its fiscal capacity instead of simply attempting to reduce and control social policy costs while cutting or stabilizing tax levels.

Yet tax competition and global governance issues are also on the agenda for the future financing of the welfare state. The fact that the deregulation of capital markets has increased the freedom of movement of tax bases, notably capital, has had repercussions on financing mechanisms. Corporate taxes are showing a downward trend, not least in Europe. While labour is the primary tax base in terms of funding the welfare state, the erosion of other tax bases may still have repercussions on welfare state funding. The effects of an increased mobility of labour in terms of tax/welfare state competition are not straightforward either because low taxes and high benefits may be equally attractive.

\section{Suggested further reading:}

Cichon, M.; Scholz, W.; van de Meerendonk, A.; Hagemejer, K.; Bertranou, F.; Plamondon, P. (2004) Financing social protection. Quantitative Methods in Social Protection Series.

Geneva : International Labour Office/International Social Security Association. 
Ganghof, S. (2008) The politics of income taxation: a comparative analysis. Colchester: European Consortium for Political Research Press.

Manow, P. (2010) « Trajectories of Fiscal Adjustment in Bismarckian Welfare Systems » in

B. Palier (ed.) A long goodbye to Bismarck?, Amsterdam : Amsterdam University Press.

Sjöberg, O. (2000), Duties in the Welfare State. Working and paying for social rights.

Swedish Institute for Social Research Dissertation Series No. 42.

\section{REFERENCES}

Adema, W. and M. Ladaique (2009), "How Expensive is the Welfare State? Gross and Net Indicators in the OECD Social Expenditure Database (SOCX)”, OECD Social, Employment and Migration Working Papers, No. 92, OECD Publishing.

Barrientos, A. (2008) 'Financing Social Protection.' in A. Barrientos and D. Hulme (eds.) Social Protection for the Poor and Poorest: Concepts, Policies and Politics, Palgrave.

Béland, D. (2011) « Taxation and the Politics of Social Policy » paper presented at the Annual Meeting of the Research Committee 19 of the International Sociological Associated, Seoul, South Korea, 25-27 August.

Campbell, J. L. (2009) “Epilogue: a renaissance for fiscal sociology?” in I. Martin, A. Mehrotra and M. Prasad (eds), The New Fiscal Sociology: Taxation in a Comparative and Historical Perspective, Cambridge: Cambridge University Press.

Cichon, M.; Scholz, W.; van de Meerendonk, A.; Hagemejer, K.; Bertranou, F.; Plamondon, P. (2004) Financing social protection. Quantitative Methods in Social Protection Series. Geneva : International Labour Office/International Social Security Association.

De Deken, J. (2009) « Depoliticising the financing of the welfare state? Financial profiling and the hidden costs of privatised retirement provisions », paper presented at the 2009 ESPANET Conference in Urbino, Italy September 17-19. 
Esping-Andersen, Gøsta (1996) "Welfare states without work: the impasse of labour shedding and familialism in Continental European social policy", in G. Esping-Andersen (ed.), Welfare states in transition, Sage Publications.

Ganghof, S. (2008) The politics of income taxation: a comparative analysis. Colchester: European Consortium for Political Research Press.

Hacker, J. (2002) The Divided Welfare State: The Battle over Public and Private Social Benefits in the United States, Cambridge: Cambridge University Press.

Howard, C. (1997) The Hidden Welfare State: Tax Expenditures and Social Policy in the United States. Princeton: Princeton University Press.

Hujo, K. and McClanahan, S. (eds.) (2009) Financing Social Policy: Mobilizing Resources for Social Development. Palgrave/Macmillan.

Kangas, O. and Palme, J. (2007) « Social Rights, Structural Needs and Social Expenditures » in J. Clasen and N. Siegel (eds.) Investigating Welfare State Change, Cheltenham: Edward Elgar, pp. 106-29.

Kemmerling, A. (2002) “The Employment Effects of Different Regimes of Welfare State Taxation: An empirical Analysis of Core OECD-Countries", Max-Planck-Institut für Gesellschaftsforschung, Discussion Paper 02/8, Cologne.

Korpi, W. and Palme, J. (1998) “ The Paradox of Redistribution and Strategies of Equality: Welfare State Institutions, Inequality and Poverty in the Western Countries ", American Sociological Review, 63:661-87.

Manow, P. (2010) « Trajectories of Fiscal Adjustment in Bismarckian Welfare Systems » in B. Palier (ed.) A long goodbye to Bismarck?, Amsterdam : Amsterdam University Press.

Morel, N. (2007) « From subsidiarity to "free choice": child- and elderly-care policy reforms in France, Belgium, Germany and the Netherlands », Social Policy \& Administration, 
41(6):618-637.

Morel, N., Palier, B., Palme, J. (eds.) (2012) Towards a social investment welfare state? Ideas, Policies and Challenges. Bristol : Policy Press.

Obinger, H. and Wagschal, U. (2010) "Social Expenditure and Revenues" in F. Castles, S.Leibfried, J. Lewis, H. Obinger, and C. Pierson (eds.) The Oxford Handbook of the Welfare State, Oxford : Oxford University Press.

Palier, B. (2004) La réforme des systèmes de santé. Paris: PUF, Coll. Que sais-je?

Palier, B. (ed.) (2010) A Long Goodbye to Bismarck? The Politics of Welfare Reform in Continental Europe. Amsterdam: Amsterdam University Press.

Palme, J., Nelson, K., Sjöberg, O., and Minas, R. (2009) European Social Models, Protection and Inclusion. Stockholm: Institute for Futures Studies, Research Report 2009/1.

Pierson, P. (ed.) (2001) The New Politics of the Welfare State. Oxford: Oxford Univerity Press.

Scharpf, F. (2000) 'Economic changes, vulnerabilities, and institutional Capabilities', in F. Scharpf and V. Schmitd (eds) Welfare and work in the open economy. From vulnerability to competitiveness, Oxford, Oxford University Press.

Sjöberg, O. (2000), Duties in the Welfare State. Working and paying for social rights. Swedish Institute for Social Research Dissertation Series No. 42.

Swank, D. and Steinmo, S. (2002) "The new political economy of taxation in advanced capitalist democracies", American Journal of Political Science, 46:642-655. 